Acta vet. scand. $1961,2,311-316$.

From the Veterinary Bacteriological Laboratory, Västerås, Sweden.

\title{
STAPHYLOCOCCUS AUREUS AS THE CAUSE OF ABORTION IN SWINE
}

By

\author{
H. Thörne and P. O. Nilsson
}

Enzootic abortion in swine has not occurred in Sweden, excepting a local outbreak in the middle of the 1950s. Sporadic cases of abortion in swine, on the other hand, are not rare. The causation of these sporadic abortions is often difficult to establish. Trauma, toxins, infections, systemic diseases, metabolic disorders, etc., are possible causes $(2,7,8,12)$.

A report will here be given of clinical, pathological and bacteriological observations in a case of abortion in swine, apparently caused by staphylococci.

Reports on findings of staphylococci in cases of abortion in domestic animals are relatively sparse. Benesch (2) and Roberts (12) mention staphylococci as a cause of abortions in mares. Dimock et al. (3) demonstrated staphylococci in $2 \%$ of infected foetuses from mares. Doll et al. (4), by analysis of a large material, found that staphylococci were isolated in less than $1 \%$ of infected foetuses from mares. Pounden et al. $(9,10)$ report the presence of staphylococci in 5 cases of abortion in a herd of 50 cows. Gilman (6) considers that only solitary cases of abortion in cows are due to staphylococci. According to Roberts (12), sporadic cases of abortion with findings of staphylococci occur in dogs and cats. Fennestad et al. (5) report a case of staphylococcal infection in the accessory gonads in a boar. The boar had served a number sows, some of which had become pregnant. Two aborted and staphylococci were isolated from the foetuses and the foetal membranes, respectively. Ringarp (11) isolated Staph. aureus at bacteriological examination of uterine secretion in 1 out of 127 sows with agalactia. 


\section{OWN INVESTIGATIONS}

Clinical observations

In a herd including 4 mother sows one of these aborted on Feb. 17, 1961. The sow had been mated on Nov. 21, 1960, and so the abortion occurred after 87 days of pregnancy. The number of dead expelled foetuses was 13. The placenta was expelled and after completed abortion the sow appeared to be in good health. For about 2 weeks thereafter a fairly sparse purulent discharge from the vulva was noticed. The sow's udder was clinically normal.

Pathologic-anatomical observations

Three of the foetuses and the placenta were examined on the day after the abortion. The other 10 foetuses were examined 2 days later, having been stored cold at the farm.

All the foetuses showed a similar picture at autopsy. All were well developed, $18-19 \mathrm{~cm}$. in length from the first cervical to the first caudal vertebra. There were no or insignificant postmortem changes. The spleen was slightly swollen and hyperaemic. The liver was slightly swollen and moderately hyperaemic. The gastric contents were of varying colour, from yellow to pale red. In all the foetuses the meninges showed vascular injection.

Histological examination of the liver, the kidneys, the lungs and the brain from two of the foetuses revealed:

In the liver: Accumulations of round-cell infiltrates (haematopoetic foci) in a large number.

In the kidneys: No abnormalities.

In the lungs: Accumulations of round-cells and erythrocytes in the large bronchi in one of the foetuses.

In the brain: Marked hyperaemia and oedema in the meninges.

The placenta showed macroscopically slight hyperaemia. In the placenta were seen a few well-defined undetachable firm yellowish white areas, $2 \mathrm{~cm}$. in diameter and $1-2 \mathrm{~mm}$. in thickness.

Histologically the allantochorion showed signs of placentitis with fairly slight cell-infiltration of the connective tissue. The above-described areas, which histologically had a necrotic appear- 
ance with some calcifications and showed no inflammatory reactions, should probably be interpreted as physiological (hippomanes) (1).

The amniotic fluid was diffusely turbid and of a yellowishred colour.

\section{Bacteriological observations}

All the foetuses, the placenta and uterine secretion from the sow were examined bacteriologically.

In all the 13 foetuses bacteriological examination was made of gastric contents and of the spleen, and in 9 of heart-blood and the meninges as well. A total of 44 samples from 13 foetuses were thus examined. All these samples yielded a pure growth of staphylococci in large numbers and of uniform appearance (Fig.).

Staphylococci in virtually pure cultures with identical manner

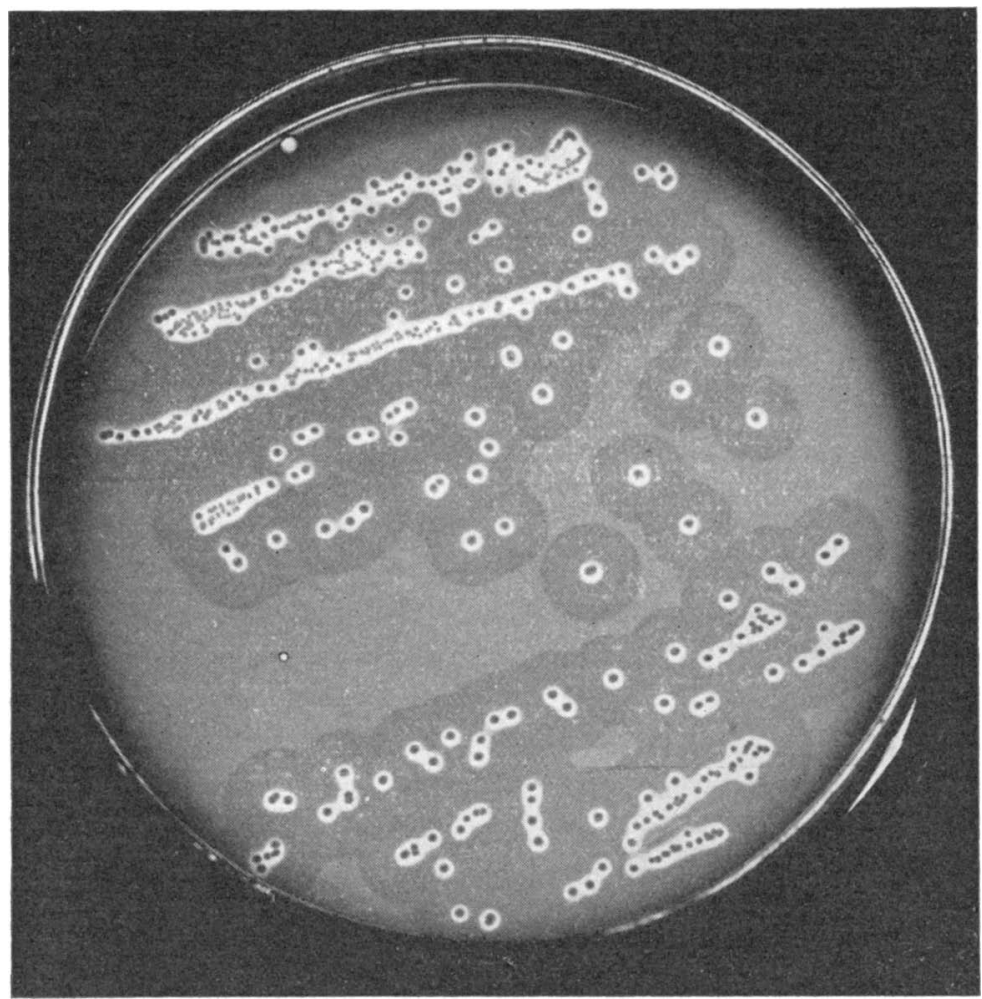

Growth obtained from the meninges in an aborted foetus (5\% cattleblood agar after 24 hours at $37^{\circ} \mathrm{C}$ ). 
of growth were also obtained from the placenta and amniotic fluid.

Two swabs of uterine secretion from the sow were taken 3 days and 3 weeks, respectively, after the abortion. These samples, too, yielded virtually pure cultures of staphylococci with the same manner of growth.

Examination for the presence of Brucella in the foetuses, the placenta and uterine secretion was negative.

A total of 48 Staphylococcus strains from the foetuses, the placenta, amniotic fluid and uterine secretion from the sow were thus isolated.

All these strains were subjected to a series of tests and all showed identical characteristics: The strains grew on rabbitblood and cattle-blood agar with greyish-yellow colonies surrounded by a narrow zone of total haemolysis, on cattle-blood agar by a wide $\beta$-toxin zone as well. The cAMP reaction was positive. The strains fermented in $\mathbf{2 4}$ hours mannite, lactose, glucose, maltose and saccharose but not rhamnose; the Voges-Proskauer test was negative, the methyl-red test positive. Gelatin was liquefied. Rabbit plasma was coagulated in $2 \frac{1}{2}$ hours.

Phage-typing: Two Staphylococcus strains from each of the 13 foetuses, the two strains from the placenta and the two strains isolated from the uterine secretion were tested against the following phages: $29,52,52 \mathrm{~A}, 79,80,81$, KS6; 3A, 3B, 3C, 55, 71; 6, 7, $42 \mathrm{E}, 47,53,54,75,77,83,83 \mathrm{~A}, 42 \mathrm{D}$, and 187 . All the strains gave an identical phagepattern: 29/52/52A/79/80/81/KS6/6/7/77+. Test for pathogenicity in experimental animals: $0.5 \mathrm{ml}$. of an 18-20 hour broth culture of three of the Staphylococcus strains was injected subcutaneously in mice. All the three mice died within 24 hours. Autopsy showed the picture of sepsis and general infection with staphylococci having the same biological properties as those described above. On intracutaneous injection in rabbits dermatonecrosis developed at the site of injection.

\section{DISCUSSION}

At bacteriological examination of various organs from 13 aborted swine foetuses pure cultures of Staph. aureus were obtained. Culture of the placenta and uterine secretion from the sow yielded virtually pure growth of Staph. aureus. All the isolated strains were identical. No other cause of the abortion, for instance brucellosis, was demonstrated. The staphylococcal 
infection was thus in all likelyhood the primary cause of the abortion in this case. Coital infection is however unprobable. The staphylococci were probably conveyed to the uterus in the later stage of pregnancy from, e.g., the udder or the throat. No clinical signs of mastitis occurred, and consequently the throat or some other part of the digestive tract has to be regarded as the most probable portal of entry. The biological properties of the isolated Staphylococcus strain do not differ from those of the staphylococci that may occur in bovine mastitis $(13,14,15)$. Possibly, the staphylococci can have entered with the milk included in the feed.

\section{ACKNOWLEDGEMENTS}

The authors want to express their best thanks to G. Wallmark, M.D., of the State Bacteriological Laboratory, Stockholm, for carrying out the phage-typing, and to $A$. Bane, associate professor, of the Department of Obstetrics and Gynaecology, Royal Veterinary College, Stockholm, for advice and help.

\section{REFERENCES}

1. Bane, A.: Personal communication. 1961.

2. Benesch, $F$. in Wirth, D.: Lexikon der praktischen Therapie und Prophylaxe für Tierärzte. 1948.

3. Dimock, W. W., Edwards, P. R. \& Bruner, D. W.: Cornell Vet. 1947, $37,89$.

4. Doll, E. R., Bruner, D. W. \& Kinkaid, Alice S.: J. Amer. vet. med. Ass. 1949, 114, 292.

5. Fennestad, K. L., Støvlbæk Pedersen, P. \& Mфller, T.: Nord. Vet.Med. 1955, 7, 929.

6. Gilman, H. L.: Cornell Vet. 1939, $29,153$.

7. Glässer, K., Hupka, E. \& Wetzel, R.: Die Krankheiten des Schweines. Hannover 1950.

8. Lagerlöf, N. P.: Kompendium i obstetrik. 1945.

9. Pounden, W. D. \& Krauss, W. E.: J. Amer. vet. med. Ass. 1947, $111,35$.

10. Pounden, W. D., Ferguson, L. C., Knoop, C. S. and Krauss, W. E.: J. Amer. vet. med. Ass. 1947, 111, 376.

11. Ringarp, N.: Acta agr. scand. 1960, Suppl., 7.

12. Roberts, S. J.: Veterinary Obstetrics and Genital Diseases. Ithaca, New York 1956.

13. Thörne, H.: Nord. Vet.-Med. 1957, 9, 521.

14. Thörne, $H$. and Wallmark, G.: Acta vet. scand. 1960, $1,114$.

15. Wallmark, G. and Thörne, H.: Nord. Vet.-Med. 1958, 10, 76. 


\section{SUMMARY}

In a case of abortion in swine pure cultures of Staph. aureus were obtained from various organs of 13 aborted foetuses. Specimens of the placenta and uterine secretion yielded virtually pure growth of Staph. aureus. The isolated strains showed identical biological properties and an identical phage-pattern. The staphylococcal infection is considered to have been the primary cause of the abortion. Possible paths of infection are discussed.

\section{ZUSAMMENFASSUNG}

Staphylococcus aureus als Ursache von Abortus beim Schwein.

In einem Falle von Abortus beim Schwein wurde Staphylococcus aureus in Reinkultur in verschiedenen Organen bei 13 abortierten Fötussen ermittelt. In der Nachgeburt und im Uterussekret wurde ebenfalls Staphylococcus aureus, praktisch genommen, in Reinkultur nachgewiesen. Die isolierten Staphylokokkenstämme zeigten identische biologische Eigenschaften und identisches Phagenmuster. Die Staphylokokkeninfektion wird als die primäre Abortusursache betrachtet. Mögliche Infektionswege werden diskutiert.

\section{SAMMANFATTNING}

Staphylococcus aureus som orsak till abort hos svin.

Vid ett fall av abort hos svin påvisades Staphylococcus aureus i renkultur i olika organ hos 13 aborterade foster. I efterbörd och uterussekret påvisades också Staphylococcus aureus i praktiskt taget renkultur. De isolerade stafylokockstammarna visade identiska biologiska egenskaper och identiskt fagmönster. Stafylokockinfektionen anses vara den primära kastningsorsaken. Möjliga infektionsvägar diskuteras.

(Received Juni 27. 1961). 